\title{
The Characteristics of Imipenem-Resistant Bacteria Isolated from One Patient
}

\author{
Chul Park ${ }^{1}$, Hyeok-Jae Lee ${ }^{2}$, Min-Young Seo ${ }^{2}$ \\ ${ }^{1}$ Department of Clinical Laboratory Science, Gwangyang Health Science University, Gwangyang, Korea \\ ${ }^{2}$ Department of Biomedical Laboratory Science, Gwangju Health Science University, Gwangju, Korea
}

\section{한 환자에게서 분리된 Imipenem 내성세균들의 특성}

\author{
박 철 ${ }^{1}$, 이혁재 ${ }^{2}$, 서민영 ${ }^{2}$ \\ ${ }^{1}$ 광양보건대학교 임상병리과, ${ }^{2}$ 광주보건대학교 임상병리과
}

\begin{abstract}
Four imipenem-resistant bacteria were isolated from the clinical specimens of a patient with pneumonia. To identify the isolates, we used the GN card of Vitek II system and performed a phylogenetic analysis based on $16 \mathrm{~S}$ rRNA gene sequence. The isolates were identified as $P$. aeruginosa (2 strains), $P$. monteilii( 1 strain), and $P$. putida (1 strain), and were tested for antibiotic resistance after determining the MIC of imipenem to be $\geqq 8 \mu \mathrm{g} / \mathrm{mL}$ using the AST-N225 card of Vitek II system. The imipenem-resistant genotypes were determined using PCR products amplified using specific $\beta$-Lactamase gene primers. The MBL gene was identified in all four isolates. One strain of $P$. aeruginosa exhibited the VIM and SHV-1 type genes, while the other strain exhibited both VIM and OXA group II genes. According to the antimicrobial susceptibility test, the bacteria were more susceptible to amikacin than other antibiotics. DNA fingerprint analysis using ERIC-PCR to analyze the epidemiological relationship between strains estimated that both the $P$. aeruginosa isolates were similar, but exhibited different DNA band types. It is uncommon to find four strains of imipenem-resistant bacteria with different DNA band types in a single patient.
\end{abstract}

Key words: ERIC (Enterobacterial repetitive intergenic consensus)-PCR, Imipenem-resistant bacteria, MBL (Metallo- $\beta$-lactamase) gene

This is an Open Access article distributed under the terms of the Creative Commons Attribution Non-Commercial License (http://creativecommons.org/licenses/by-nc/4.0) which permits unrestricted non-commercial use, distribution, and reproduction in any medium, provided the original work is properly cited.

Copyright @ 2017 The Korean Society for Clinical Laboratory Science. All rights reserved.
Corresponding author: Chul Park Department of Clinical Laboratory Science, Gwangyang Health Science University, 85 Daehakro, Gwangyang 57764, Korea Tel: 82-61-760-1443

Fax: 82-61-760-9009 E-mail: pcggs11070417@gy.ac.kr

Received: October 13, 2017 Revised $1^{\text {st. }}$ October 23, 2017

Revised 2 ${ }^{\text {nd }}$ : October 31, 2017 Revised 3 ${ }^{\text {rd: }}$ November 2, 2017 Revised 4 ${ }^{\text {th }}$ : November 6, 2017 Revised $5^{\text {th }}$ : November 8, 2017 Accepted: November 8, 2017

\section{서 론}

1980년대 이후로부터 각종 cephalosporin제제와 aminoglycoside, tetracycline, monobactam, quinolone, cabapenem, glycopeptide 등 많은 종류의 항생제가 개발되어 실제 임상에서 사용 되었다. 그러나이시기에는 penicillin 내성 폐렴 구균 등이 세계 각지에서 문제가 되기 시작 하였고, imipenem-resistant Acinetobacter baumannii 균주도 영국에서
처음 분리가 되었으며, 1990년대에는 vancomycin resistant enterococcus (VRE)가 출현하면서, 항생제 내성세균의 문제 는 세계적인 관심사로 대두되었다[1]. 그 후로는 그람 양성균의 최종 치료제라고 여겨지던 glycopeptide제제인 vancomycin 에 내성인 vancomycin intermediate stapylococcus aureus (VISA)가 일본에서 처음으로 1996년에 출현함으로서 효용성 이 심각하게 흔들리기 시작하였다. 그리고 광범위 $\beta$-lactamase (extended spectrum $\beta$-lactamase, ESBL)를 생성하는 그람 음 
성균의 빈도도 증가하기 시작하여 $\beta$-Lactamase의 효과적인 치료를 위해 carbapenem 항생제를 사용 하였다. 최근에는 carbapenem 항생제 사용이 빈번해지면서 Pseudomonas aeruginosa, Acinetobacter baumannii, Enterobacter cloacae, Serratia marcescens 등에서 carbapenem 내성인 세균들이 점 차적으로 증가하기 시작하였다. 이러한 세균들의 내성기전으 로는 주로 세포막의 투과성 감소와 항균제의 유출 그리고 carbapenemase 생성 등에 의해 나타나는데 획득성 carbapenemase에 의한 내성은 다른 균들에게 그 내성유전자를 전달 할 수 가있어 이러한 세균들의 전파로 인한 감염증 치료와 더불 어 내성 확산의 우려가 대두되고 있다[2]. Carbapenemase에 는 class A, B, D 등이 있는데 class D 군에는 OXA형이 있으며 주로 광범위 $\beta$-lactam 항생제들을 가수분해하지만 carbapenem 의 가수분해 능력이 약하거나 일부 extended spectrum- $\beta-\mathrm{lac}-$ tam제를 가수분해 하지 못하며 아직까지는 분리빈도는 작지만 carbapenem을 가장 잘 분해하는 것은 class B이며, 효소의 활 성을 위해 $\mathrm{Zn}^{2+}$ 과 같은 금속이온이 필요하기 때문에 metallo- $\beta$-lactamase (MBL)로 명명되었으며[3] 대표적인 MBL로는 IMP (active on imipenem), VIM (Verona integron-encoded metallo- $\beta$-lactamasea)이 대표적이며, SPM (Sao Paulo metallo- $\beta$-lactamase)과 GIM (German imipenemase), SIM (Seoul imipenemase) 등도 보고되었다[4,5].

국내 여러 병원에서 2003년에 분리된 imipenem내성 $\mathrm{Pseu}-$ domonas spp.의 $11.1 \%$ 와 Acinetobacter spp.의 $15.1 \%$ 는 IMP-1 또는 VIM-2 MBL 생성균이었다[6]. 아시아, 유럽, 남, 북 아메리카를 포함한 전 세계적으로 보고되고 있으며 브라질에서 도 SPM-1 [7]이 보고되었다. IMP-1형 MBL 생성균은 1991년 일본에서 P. aeruginosa로부터 처음 분리되었으며[8] 주로 일 본, 아시아 및 유럽에서도 분리 보고 되었다[9]. VIM-1형은 이 태리에서 처음 분리되었으며[10] 이어서 프랑스에서 VIM-2형 이 분리 되었다[11]. 그 이후 대만 및 그리스에서 VIM-3형 및 VIM-4형[12]이 각각 보고 되었는데, 국내에서는 1995년 분리 된 P. aeruginosa에서 VIM-2형이 처음 분리되었으며[13], Acinetobacter, S. marcescens [14] 및 E. cloacae [15]등에서 도 분리 되었다. 일본에서는 IMP-1형이 주로 분리되는 반면에 우리나라는 VIM-2형이 대부분을 차지하였다[6]. 이에 본 연구 에서는 전남 순천에 위치한 종합병원 중환자실에서 폐렴으로 입원한 한 환자에게서 검체는 다르지만 imipenem 내성세균이 반복 분리됨으로서 carbapenemase 생성균주 선별검사와 $\beta$-lactamase 유전자형을 알아보고 균주간의 역학적 연관성 분 석을 위해 ERIC (enterobacterial repetitive intergenic con-
sensus)-PCR을 이용한 DNA 지문 분석을 하였다.

\section{재료 및 방법}

\section{1. 연구대상}

2017년 2월부터 2017년 3월사이 전남 순천의 한 종합병원 에서 폐렴으로 입원한 한(일개) 환자의 임상검체에서 분리된 carbapenem의 대표적 약제인 imipenem에 내성을 가진 균주 를 Vitek II system (BioMerieux, Marcy, 1'Eltoile, France) AST-N225 카드를 이용해서 imipenem의 최소억제 농도 (MIC)가 모두 $\geqq 8 \mu \mathrm{g} / \mathrm{mL}$ 을 확인한 후 본 실험에 사용하였다. 환자의 검체로는 객담, 기관지 세척액, 농, 소변으로 각각 다르 지만 동일 환자에게서 imipenem에 내성인 균주가 2개월 사이 에 연속 분리됨으로서 총 4 균주를 대상으로 연구 하였다.

\section{2. 균주의 동정}

순수 분리한 imipenem에 내성인 균주 동정은 미생물 자동 동정기기인 Vitek II system의 GN 카드를 이용하였고, 종까지 정확하게 동정되지 않았던 균주를 보다 정확한 동정을 위해서 $16 \mathrm{~S} \mathrm{rRNA}$ 유전자의 염기서열을 이용하여 계통학적 방법으로 분석 하였다.

\section{DNA 추출}

MHA (Mueller-Hinton Agar) 배지에서 자란 세균집락 1 loop를 채취하여 Park과 Kim [16] 의 방법에 따라서 DNA를 추 출하였고 차가운 $70 \%$ ethanol로 세척 한 후 건조해서 $-20^{\circ} \mathrm{C}$ 에 냉동 보관하였으며 사용시 멸균된 증류수에 녹여 실험에 이 용하였다.

\section{4. 계통분류학적 연구(16S rRNA유전자 염기서열 분석)}

$16 \mathrm{~S} \mathrm{rRNA}$ 유전자를 증폭하기 위해 27F (5'-AGA GTT TGA TCM TGG CTC AG-3')와 1492R (5'-GGY TAC CTT GTT ACG ACT T-3') primer를 사용하였으며[17] PCR 반응액의 조 성 및 증폭조건은 Hwang 등[18]의 방법을 이용하였으며 PCR thermal cycler TP600 (Takara Bio Inc., Japan)을 이용하여 증폭하였다. 염기서열 분석은 (주) 제노텍(GenoTech, Daejeon, Korea)에 의뢰하였으며 결정된 $16 \mathrm{~S} \mathrm{rRNA}$ 유전자 염기서열의 종간 유사도는 BLAST을 이용하여 GenBank 데이터베이스와 비교 검색하였다[16]. 계통수 작성은 neighbor-joining [19]방 법을 이용하였으며 진화거리는 Jukes와 Cantor [20]의 식을 이 용하였다. 계통수의 신뢰도는 1,000 회 반복을 통한 bootstrap 
분석[21]을 실시하여 확인하였다.

\section{5. 항생제 감수성 검사}

항생제의 MIC측정은 Vitek II system의 AST-N225 카드로 측정 하였으며 imipenem에 내성인 균주는 디스크 확산법으로 McFarland 0.5관에 맞춘 세균 현탁액을 MHA 배지에 접종한 후 $10 \mu \mathrm{g}$ imipenem 항생제 디스크(Becton Dickinson, BBL, Sparks, USA)를 올려놓고 $37^{\circ} \mathrm{C}$ 에서 $16 \sim 18 \mathrm{hr}$ 배양한 후 억제 대의 직경은 CLSI 기준에 의해 판독하였다[22]. 대조 균주로는 P. aeruginosa ATCC 27853을 사용하였다.

\section{Carbapenemase 생성균주 선별}

분리된 균주가 carbapenemase 생성 검증을 위해 Hodge 변 법으로 확인하였다. 시험은 E. coli ATCC 2592를 생리식염수 로 McFarland 0.5관 탁도를 맞추어 $\mathrm{MHA}$ 평판배지에 접종한 후 배지 중앙에 imipenem 디스크를 올려놓은 후 중앙으로부터 배지 끝부분을 향해 시험 세균을 일직선으로 접종하고 $37^{\circ} \mathrm{C}$ 에 서 16 20 hr 배양하였다. 결과 판정 기준은 시험한 균주 접종 선 중앙쪽 말단부가 다른 부위에 비해 더 넓게 증식하면 양성으 로 판정 하였다[16].

\section{7. $\mathrm{MBL}$ 검증}

분리된 균주가 MBL 생성 검증을 위해 Imipenem-EDTA 디 스크 상승효과 시험을 실시하였다. 선별 시험은 균주를 생리식 염수에 McFarland 0.5관 탁도로 맞추어 MHA 배지에 접종한 후 $10 \mu \mathrm{g}$ imipenem 디스크와 $0.5 \mathrm{mM} \mathrm{EDTA} 10 \mu \mathrm{L}$ 가 함유된 디스크를 $10 \mathrm{~mm}$ 거리가 되게 올려놓고 16 18시간동안 배양
한 후 억제대의 확장현상이 관찰되면 양성으로 판정하였다[16].

\section{PCR을 이용한 $\beta$-lactamase 유전자형 분석}

$\beta$-Lactamase 유전자형을 검사하기 위해 기존에 알려진 primer는 Table 1 [16]과 같이 사용하였으며 OXA group I은 OXA-5, OXA-7, OXA-10 and derivatives (OXA-11, OXA-14, OXA-16, OXA-17)과 OXA-13 and derivatives (OXA-19, OXA-28)를 OXA group II는 OXA-2, OXA-3, OXA-15, OXA-20을 OXA group III은 OXA-1, OXA-4, OXA-30, OXA-31을 각각 포함한다[23]. 그리고 이들 각각의 primer를 이용하여 PCR을 실시하여 증폭하였다. PCR 반응액은 $\mathrm{dNTP}$ (각 $2.5 \mathrm{mM}$ ), $\mathrm{MgCl}_{2} 2 \mathrm{mM}$, primer 각 $20 \mathrm{pmol}$, Taq DNA polymerase (Bioneer, Korea) 0.5 U, genomic DNA $100 \mathrm{ng}$ 및 반응완충용액 $(10 \mathrm{mM}$ Tris- $\mathrm{HCl}, 40 \mathrm{mM} \mathrm{KCl}, 1.5 \mathrm{mM}$ $\mathrm{MgCl}_{2}$ )에 총 부피가 $50 \mu \mathrm{L}$ 가 되도록 증류수를 첨가하였고 $\mathrm{PCR}$ 반응은 PCR thermal cycler TP 600 (Takara Bio, Foster City, $\mathrm{CA}, \mathrm{USA})$ 을 이용하였으며 $\mathrm{PCR}$ 반응 조건은 $95^{\circ} \mathrm{C}$ 에서 5 분간 초기 denaturation 시키고, $95^{\circ} \mathrm{C}$ 에서 30 초, $59^{\circ} \mathrm{C}$ 에서 30 초, $72^{\circ} \mathrm{C}$ 에서 40 초의 cycle을 30 회 반복 한 후 마지막으로 $72^{\circ} \mathrm{C}$ 에 서 10 분 동안 반응 시켰다. PCR 산물은 $2.5 \%$ agarose gel에 전 기영동한 후 확인하였다[16].

\section{ERIC (enterobacterial repetitive intergenic consensus)-PCR을 이용한 DNA 지문분석}

균주간 역학적 연관성을 알아보기 위해 ERIC-PCR을 Park 과 $\operatorname{Kim}[16]$ 의 방법에 따라 실시하였다. 장내세균의 반복서열 primer ERIC1R (5'-ATG TAA GCT CCT GGG GAT TCA C-3')

Table 1. Primers used to detection $\beta$-lactamase gene and the amplified fragment size

\begin{tabular}{|c|c|c|c|c|}
\hline Class & Primer & Sequence $\left(5^{\prime} \rightarrow 3^{\prime}\right)$ & Target $\beta$-lactamase & Amplicon size (bp) \\
\hline \multirow[t]{2}{*}{ A } & SHV-F & CCG GGT TAT TCT TAT TTG TCG CT & SHV-1 and derivative & 831 \\
\hline & SHV-R & TAG CGT TGC CAG TGC TCG & & \\
\hline \multirow[t]{4}{*}{ B } & IMP-F & GCT ACC GCA GCA GAG TCT TTG & IMP & 657 \\
\hline & IMP-R & CCT TTA ACC GCC TGC TCT AAT G & & \\
\hline & VIM-F & GTT TGG TCG CAT ATC GCA AC & VIM & 581 \\
\hline & VIM-R & AGA CCG CCC GGT AGA CC & & \\
\hline \multirow[t]{10}{*}{ D } & OXA-1F & AGC CGT TAA AAT TAA GCC C & OXA group III & 908 \\
\hline & $O X A-1 R$ & CTT GAT TGA AGG GTT GGG CG & & \\
\hline & $\mathrm{OXA}-2 \mathrm{~F}$ & GCC AAA GGC ACG ATA GTT GT & OXA group II & 700 \\
\hline & $O X A-2 R$ & GCG TCC GAG TTG ACT GCC GG & & \\
\hline & OXA-10F & TCT TTC GAG TAC GGC ATT AGC & OXA group I & 760 \\
\hline & OXA-10R & CCA ATG ATG CCC TCA CTT TCC & & \\
\hline & OXA-24F & GTA CTA ATC AAA GTT GTG AA & OXA-24, 25, 26, 40, 72 & 1,058 \\
\hline & $O X A-24 R$ & TTC CCC TAA CAT GAA TTT GT & & \\
\hline & OXA-58F & CGA TCA GAA TGT TCA AGC GC & OXA-58 & 528 \\
\hline & OXA-58R & ACG ATT CTC CCC TCT GCG C & & \\
\hline
\end{tabular}


와 ERIC2 (5'-AAG TAA GTG ACT GGG GTG AGC G-3')를 주 문제작(Bioneer Co., Daejeon, Korea)하여 전기영동 한 후 Ethidium bromide 용액(10 mg/mL)에서 10 분간 염색하고 gel 사진을 저장하였고 Gelcompar II program (Applied Maths, Belgium)을 이용하여 band pattern 간 유사도를 결정 하였으며, Gel image는 TIFF file format으로 저장하였다. 그리 고 negative image로 변환한 후 normalization 과정을 통해 각 기 다른 gel 상의 size marker와 pattern들을 표준화하였으며, band-matching algorithm은 Dice-coefficient를 이용한 paired-wise similarity 계산 방법을 이용하고 band-matching tolerance는 $0.75 \%$ 로 선택하였으며 Similarity matrice의 cluster 분석은 UPGMA (unweighted pair group method using arithmetic average)에 의해 수행하였다[16].

\section{결 과}

\section{1. 균주의 분리 및 동정}

2017년 2월부터 2017년 3월사이 한 종합병원 중환자실에서 폐렴으로 입원한 한(일개) 환자의 임상검체에서 분리된 imipenem에 내성을 가진 균주를 Vitek II system의 GN 카드 를 이용해 동정한 결과 객담, 기관지 세척액 검체에서 P. aeruginosa를 각각 1균주씩 분리하였고 농과 소변검체에서 $P S e u-$ domonasspp.로 동정된 균주를 $16 \mathrm{~S} \mathrm{rRNA}$ 유전자 염기서열 분 석을 이용한 계통분류학적 분석에 의해 P. monteilii, P. putida

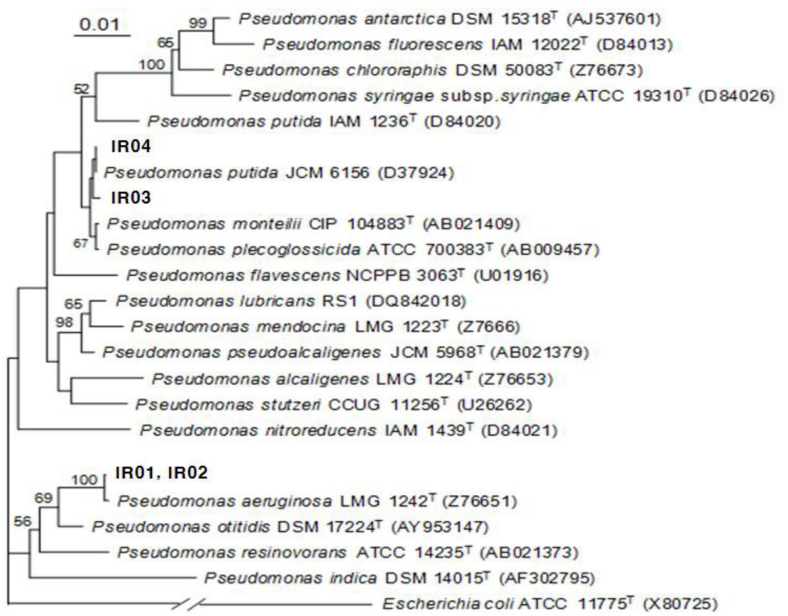

Figure 1. Neighbour-joining tree based on nearly complete $16 \mathrm{~S}$ rRNA gene sequences showing relationships between strains, members of the genus Pseudomonas. The percentage numbers at the nodes are the levels of bootstrap support based on neighbour-joining analyses of 1,000 resampled data sets. The sequence of Escherichia coli ATCC $11775^{\top}$ (X80725) was used as an outgroup. Bar, 0.01 nucleotide substitution per position.
로 각각 동정되었다(Figure 1).

\section{Carbapenemase 생성균주 선별검사}

Imipenem 내성 균주가 carbapenemase를 생성하는가를 알아 보는 Hodge 변법 시험결과 4균주 모두양성반응을 보였고(Figure $2 \mathrm{~A}), \mathrm{MBL}$ 생성 균주를 선별하기 위한 imipenem-EDTA 상승효 과시험에서도 4균주 모두가 양성반응을 보였다(Figure 2C).

\section{MBL 생성 검증}

$\mathrm{PCR}$ 을 통한 $\beta$-lactamase 유형 분석에서 객담과 기관지 세 척액에서 분리된 $P$. aeruginosa 2 균주와 농에서 분리한 $P$. monteilii에서 Class B $\beta$-lactamase VIM 유전자가 각각 분리 되었고 소변에서 분리된 P. putida에서는 IMP 유전자가 검출되 었다. 그리고 P. aeruginosa 2균주에서는 VIM 유전자와 함께 class A 유전자형인 SHV-1 and derivative 유전자와 Class D 유전자형인 OXA group II 유전자를 각각 공동으로 보유하고 있 었다(Table 2, Figure 3).

\section{4. 항생제 감수성}

IR01번 균주인 P. aeruginosa는 amikacin 만이 감수성이었 고 모든 항생제에서 내성을 보였고 IR02번 균주인 P. aeruginosa는 tigecycline, minocycline, ciprofloxacin, ticarcillin/clavulanic acid 감수성을 보여 IR01번 균주인 P. aeruginosa 와는 다른 항생제 감수성 경향을 보임으로서 서로 다른 균주임 을 추정 할 수 있었다. IR03번 균주인 P. monteilii는 amikacin, aztreonam, ceftazidime, piperacillin/tazobactam, ticarcillin/clavulanic acid, cefepim, gentamicin, meropenem, piperacillin에 감수성을 보였다. IR04번 균주인 P. putida는 amikacin, ciprofloxacin, gentamicin의 3가지 항생제에 감수 성을 보였으며 나머지 항생제에는 내성을 보였다(Table 3).

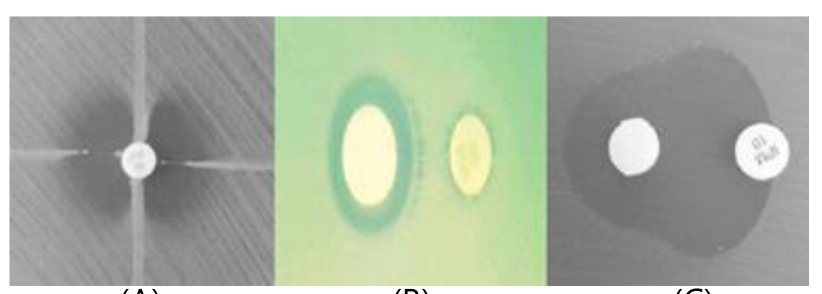

(A)

(B)

(C)

Figure 2. Modifid Hodge test (A) and EDTA double disc synergy test (B) and (C). (A) Upper and low are imipenem-hydrolyzing strains which distorted the inhibition zone. Left and right are imipenem-non-hydrolyzing strains with no effect on the zone (Negative control). (B), (C) The left disc contains $5 \mathrm{mM}$ EDTA and the right disc contains $10 \mu \mathrm{g}$ imipenem. (C) is MBL producing strain and $(B)$ is MBL non-producing strain. 
Table 2. Identification and imipenem-resistance genotype of the isolates

\begin{tabular}{cccccc}
\hline Strain No. & Specimen & Identification & $\begin{array}{c}\text { Genotype of } \\
\beta \text {-lactamase }\end{array}$ & $\begin{array}{c}\text { Modified } \\
\text { hodge test }\end{array}$ & $\begin{array}{c}\text { EDTA double disk } \\
\text { synergy test }\end{array}$ \\
\hline IR01 & Sputum & P. aeruginosa & VIM+SHV-1 & + & + \\
IR02 & BWF & P. aeruginosa & VIM+OXA group II & + & + \\
IR03 & Pus & P. monteilii & VIM & + & + \\
IR04 & Urine & P. putida & IMP & + & + \\
\hline
\end{tabular}

Abbreviation: BWF, Bronchial washing fluid.

Table 3. Antibiotic susceptibility results of 4 strains by Vitek II system

\begin{tabular}{ccccccccccccccc}
\hline $\begin{array}{c}\text { Strain } \\
\text { No. }\end{array}$ & AK & AZT & TIG & CAZ & MIN & CIP & CFP & GM & IM & MER & P/T & TIM & A/S & PIP \\
\hline IR01 & 16 & $\geqq 64$ & $\geqq 8$ & $\geqq 64$ & 8 & $\geqq 4$ & $\geqq 64$ & $\geqq 16$ & $\geqq 16$ & 4 & $\geqq 128$ & $\geqq 128$ & $\geqq 32$ & $\geqq 128$ \\
IR02 & $\geqq 64$ & $\geqq 64$ & $\leqq 0.5$ & $\geqq 64$ & $\leqq 1$ & 1 & 32 & $\geqq 16$ & $\geqq 16$ & $\geqq 16$ & $\geqq 128$ & $\leqq 8$ & $\geqq 32$ & $\geqq 128$ \\
IR03 & 8 & 2 & $\geqq 8$ & $\leqq 1$ & 2 & $\geqq 4$ & $\leqq 1$ & 4 & 8 & 2 & $\leqq 4$ & 16 & $\geqq 32$ & 16 \\
IR04 & 8 & 16 & $\geqq 8$ & 32 & $\geqq 16$ & $\leqq 0.25$ & 4 & 2 & $\geqq 16$ & 4 & $\geqq 128$ & $\geqq 128$ & $\geqq 32$ & $\geqq 128$
\end{tabular}

Abbreviations: AK, amikacin; AZT, aztreonam; TIG, Tigecycline; CAZ, ceftazidime; MIN, Minocycline; CIP, ciprofloxacin; CFP, cefepime; GM, gentamicin; IM, imipenem; MER, meropenem; P/T, piperacillin/tazobactam; TIM, ticarcillin/clavulanic acid; A/S, Ampicillin/Sulbactam; PIP, Piperacillin.

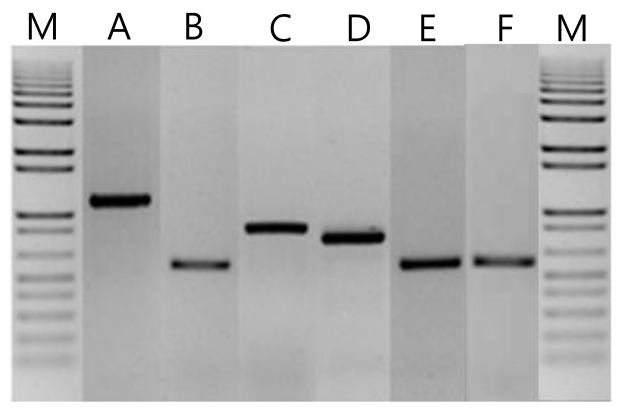

Figure 3. Detection of $\beta$-lactamase genotype isolated from 4 strains. M, 1 kb plus DNA ladder; Lanes A, P. aeruginosa IR01 (SHV-1); B, P. aeruginosa IR01 (VIM); C, P. aeruginosa IR02 (OXA group II); D, P. putida IR04 (IMP); E, P. monteilii IR03 (VIM); F, P. aeruginosa IR02 (VIM).

\section{5. 계통분류학적 분석(16S rRNA유전자 염기서열 분석)}

$16 \mathrm{~S} \mathrm{rRNA}$ 유전자 염기서열의 종간 유사도를 알아보기 위해 NCBI (National Center for Biotechnology Information)의 BLASTN program을 이용하여 GenBank database 에서 비교 • 검색하였으며 $16 \mathrm{~S}$ rRNA 유전자 염기서열에 기초하여 neighbour-joining tree를 작성하여 계통학적 위치를 확인 하였다 [16]. Vitek II system에 의해 Pseudomonas spp.로 정확하게 동정되지 않았던 균주는 P. monteilii, P. putida로 각각 동정되 었다(Figure 1).

\section{ERIC-PCR을 이용한 DNA 지문 분석}

객담, 기관지 세척액 검체에서 P. aeruginosa를 각각 1균주

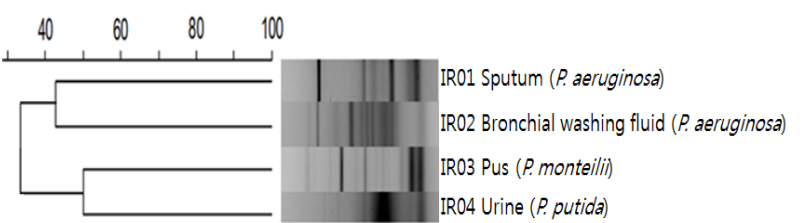

Figure 4. ERIC-PCR patterns of genomic DNA of imipenem resistant $P$. aeruginosa, $P$. monteilii and $P$. putida.

씩 분리하였고 농과 소변검체에서 P. monteilii, P. putida로 각 각 동정되었던 총 4 균주를 대상으로 DNA band 유형을 확인한 결과 동일균종에서도 서로 다른 DNA band 유형으로 확인 되었 다(Figure 4).

\section{고 찰}

$\beta$-lactam 항생제는 그람음성간균의 감염증치료에 광범위하 게 사용되어 왔지만 얼마 지나지 않아 항생제 사용의 증가는 penicillin과 광범위 cephalosporin을 가수분해하는 extended spectrum- $\beta$-lactamase를 생성하는 내성세균의 출현을 야기 시켰다. 이들 내성세균의 치료에는 비교적 안정한 carbapenem 계열의 항생제를 사용하고 있다. 그러나 이러한 항생제의 과다 사용으로 인해 carbapenem에 내성인 세균들의 출현은 임상에 서 커다란 문제로 대두되고 있으며 특히 P. aeruginosa와 $A$. baumanni가 carbapenemase를 생성하여 내성세균으로의 보 고가 전 세계적으로 점차 증가하고 있는 추세이다[24]. 또한 최근 에는 장내세균에서도 carbapenemase 생성균주가 나타나고 있 
는 실정이다[15].

본 연구는 전남 순천의 한 종합병원 중환자실에 입원한 한 환 자에게서 2개월 사이에 검체별로 imipenem 내성 세균이 연속해 서 4 균주가 분리되어 Vitek II system을 이용해서 동정과 항생제 $\mathrm{MIC}$ 분석을 하였다. 동정된 균주로는 P. aeruginosa 2 균주와 Pseudomonas spp. 2균주로 정확하게 동정 되지 않아 $16 \mathrm{~S}$ $\mathrm{rRNA}$ 유전자 염기서열 분석을 이용한 계통분류학적 분석에 의 해 P. monteilii, P. putida로 각각 동정되었다. Vitek II system에 의해 동정방법은 생화학적 특성에 의한 동정법으로 유사한 특성 을 갖는 유전종의 동정에는 한계가 있다는 것을 보여 주었다[25].

$\beta$-lactamase 특이 시발체를 사용하여 유전자형을 검출한 결 과 class A에 속한 $\beta$-lactamase인 SHV- 1 and derivative 유전 자는 1 균주, class B에 속한 metallo- $\beta$-lactamase 중 IMP 유전 자는 1 균주, 그리고 VIM 유전자는 3 균주가 검출되었으며 Class D에 속한 $\beta$-lactamase인 OXA group II 유전자도 1 균주 가 검출되었다. 특징적인 것은 종에 따른 imipenem 내성 유전 자형을 분석한 결과 2 균주의 P. aeruginosa에서 VIM 유전자와 SHV-1 and derivative 유전자, OXA group II 유전자를 각각 동시에 보유하고 있음을 알 수 있었으며 P. monteilii, P. putida 각각 1 균주들도 $\mathrm{MBL}$ 유전자인 $\mathrm{VIM}$ 유전자와 IMP 유전자를 각 각 보유하고 있어 한 환자에게서 $\mathrm{MBL}$ 유전자가 반복 분리됨으 로서 병원내 $\beta$-lactamase 내성유전자들을 확인 할 수 있었다.

Carbapenemase 생성을 알아보는 Hodge 변법 시험 결과에 서는 4 균주 모두에서 양성반응을 보였고, 특히 MBL 생성능을 보는 imipenem-EDTA disk 효과 시험 결과에서도 4 균주 모두 에서 양성반응을 보여 분자생물학적방법인 $\mathrm{MBL}$ 유전자형이 모두 검출되었던 것과 일치한 결과를 보여 주었다.

항생제 감수성검사에 대한 균주의 내성율은 IR01, IR02번 균 주는 P. aeruginosa로 같은 균종이었지만 IR01번은 amikacin 만이 감수성이었고 모든 항생제에서 내성을 보였지만 IR02번 균주는 tigecycline, minocycline, ciprofloxacin, ticarcillin/clavulanic acid 감수성을 보여 IR01번 균주인 P. aeruginosa와는 다른 항생제 감수성 경향을 보여 서로 다른 균주임 을 추정 할 수 있었다. IR03번 균주인 P. monteilii는 amikacin, aztreonam, ceftazidime, cefepim, gentamicin, meropenem, piperacillin/tazobactam, ticarcillin/clavulanic acid, piperacillin에 감수성을 보여 대체적으로 내성률이 적었지만 IR04 번 균주인 P. putida는 amikacin, ciprofloxacin, gentamicin 3 가지 항생제에만 감수성을 보였고 나머지 항생제들에서는 내 성을 보였다. 대체적으로 aminoglycoside 계통의 amikacin에 대한 내성율은 다른 항생제들 보다는 다소 낮은 내성율을 보여
주었다. 내성유전자에 따른 항생제 내성율을 보면 $P$. aeruginosa 가 P. monteilii, P. putida보다 MBL유전자와 또다른 내성 유전 자를 동시에 함께 보유하고 있어 항생제 내성율이 높을 것이라 생각했지만 결과는 유의한 차이는 볼 수 없었다.

ERIC-PCR 방법을 이용한 DNA 지문 분석결과, 한 환자에게 서 검출된 4균주 모두 서로 다른 DNA band 유형을 확인하였으 며, 특히 동일종으로 분리된 P. aeruginosa 2 균주는 호흡기유 래 검체로서 같은 균주일 것으로 판단하였으나 DNA band 유형 의 상동성이 서로 다른 band 양상을 보여 서로 다른 클론에서 유 래되었음을 알아 볼 수 있었다.

최근에 점차적으로 imipenem 내성 세균의 분리율이 증가 추세에 있는데 본 연구에서는 한명의 폐렴 환자에게서 4 균주의 imipenem 내성세균이 2개월 사이에 연속해서 분리가 되는 첫 사례로서 특히 분리된 동종의 P. aeruginosa 2균주도 역학적 연 관성이 상이함을 확인 하였다. 그러므로 이러한 내성세균들에 의한 감염은 면역력이 저하된 장기입원환자와 중환자실 환자들 에게 치료적 어려움에 당면해 있으며 환자들에 감염방지를 위 해서도 적극적인 손위생과 더불어 감염관리활동을 통해 예방해 야만 하고 진단검사의학과에서는 내성 세균종과 항생제 감수성 결과에 대한 흐름을 임상의에게 제시함으로서 항생제 내성에 대한 원내감염의 위중함을 인지시켜 주어야 할 것으로 생각된다.

\section{요 약}

폐렴의 한(일개) 환자의 임상검체에서 연속적으로 분리된 Imipenem 내성세균 4 균주를 분리하였다. 분리균을 동정하기 위해 Vitek II system의 GN card를 이용하였으며 16S rRNA유 전자 염기서열을 기초로 계통학적 분석을 실시하였다. 분리균은 P. aeruginosa (2 strains), P. monteilii (1) 및 P. putida(1)으로 동정되었다. 분리균들의 항생제에 대한 내성시험은 Vitek II system AST-N225 card를 이용해서 imipenem의 최소억제 농 도가 모두 $\geqq 8 \mu \mathrm{g} / \mathrm{mL}$ 을 확인한 후 실험에 사용하였다. $\beta$-Lactamase 유전자의 특이 시발체를 이용하여 증폭한 PCR 산 물로 imipenem 내성 유전자형을 결정하였는데 분리된 4균주 모두에서 $\mathrm{MBL}$ 유전자를 확인하였으며 2균주의 P. aeruginosa 는 MBL유전자중 VIM형과 $\mathrm{SHV}$ 형 유전자를 그리고 또다른 균주 는 VIM형과 OXA group II형 유전자를 동시에 보유하고 있었다. 항생제 감수성 결과에서는 amikacin이 다른 항생제보다 감수성 을 보였을 뿐 대체적으로 내성율이 높았다. 균주들간의 역학적 연관성 분석을 위해 ERIC-PCR을 이용한 DNA 지문 분석결과, 분리된 2 균주의 P. aeruginosa는 유사한 균주일 것으로 추정하 
였으나 DNA band 유형의 상동성은 서로 다른 유형임을 알아 볼 수 있었다. 특이하게 한 환자에게서 imipenem 내성세균이 4균 주가 검출 된 것은 이례적이며 동종의 DNA band 유형도 서로 상 이하였다.

\section{Acknowledgements: None}

Funding: The Research has been conducted by the Research Grant of Gwangju Health Science University in 2014 (3014004).

Conflict of interest: None

\section{REFERENCES}

1. Livermore DM. The impact of carbapenemases on antimicrobial development and therapy. Curr Opin Investig Drugs. 2002;3(2):218-224.

2. Lee K, Lim YS, Yong D, Yum JH, Chong Y. Evaluation of the Hodge test and the imipenem-EDTA double-disk synergy test for differentiating metallo-beta-lactamase-producing isolates of Pseudomonas spp. and Acinetobacter spp. J Clin Microbiol. 2003;41(10):4623-4629.

3. Rasmussen BA, Gluzman Y, Tally EP. Cloning and sequencing of the class B beta-lactamase gene (ccrA) from Bacteroides fragilis TAL3636. Antimicrob Agents Chemother. 1990;34(8): 1590-1592.

4. Lee K, Yum JH, Yong D, Lee HM, Kim HD, Docquier JD, et al. Novel acquired metallo- $\beta$-lactamase gene, bla(SIM-1), in a class 1 integron from Acinetobacter baumannii clinical isolates from Korea. Antimicrob Agents Chemother. 2005;49(11): 4485-4491.

5. Drieux L, Brossier F, Sougakoff W, Jarlier V. Phenotypic detection of extended spectrum betalactamase production in Enterobacteriaceae: review and bench guide. Clin Microbiol Infect. 2008;14(Suppl 1):90-103.

6. Lee KW, Lee WG, Uh Y, Ha GY, Cho J, Chong Y. VIM-and IMP-type metallo- $\beta$-lactamase producing Pseudomonas spp. and Acinetobacer spp. in Korean Hospitals. Emerg Infect Dis. 2003;9(7):868-871.

7. Toleman MA, Simm AM, Murphy TA, Gales AC, Biedenbach DJ, Jones RN, et al. Molecular characterization of SPM-1, a novel metallo- $\beta$-lactamase isolated in Latin America: report from the SENTRY antimicrobial program. J Antimicrob Chemother. 2002;50(5):673-679.

8. Watanabe M, Iyobe S, Inoue M, Mitsuhashi S. Transferable imipenem resistance in Pseudomonas aeruginosa. Antimicrob Agents Chemother. 1991;35(1):147-151.

9. Koh TH, Wang GCY, Sng LH. IMP-1 and a novel metallo- $\beta$-Lactamase, VIM-6, in fluorescent Pseudomonads isolated in Singapore. Antimicrob Agents Chemother. 2004;48(6): 23342336.

10. Lauretti L, Riccio ML, Mazzriol A, Cornaglia G, Amicosante G, Fontana R. et al. Cloning and characterization of blavim, a new integron-borne metallo- $\beta$-lactamase gene form a Pseudomonas aeruginosa clinical isolate. Antimicrob Agents Chemother. 1999;43(7):1584-1590.

11. Rasmussen BA, Bush K, Keeney D, Yang Y, Hare R, O'Gara C, et al. Characterization of IMI-1 $\beta$-lactamase, a class A carbapenem-hydrolyzing enzyme from Enterobacter cloacae. Antimicrob Agents Chemother. 1996;40(9):2080-2086.

12. Pournaras S, Tsakris A, Maniati M, Tzouvelekis LS, Maniatis AN. Novel variant (blavim-4) of the metallo- $\beta$-lactamase gene blavim-1 in a clinical strain of Pseudomonas aeruginosa. Antimicrob Agents Chemother. 2002;46(12):4026-4028.

13. Lee KW, Lim JB, Yum JH, Yong D, Chong Y, Kim JM. blavim-2 cassette-containing novel integrons in metallo- $\beta$-lactamaseproducing Pseudomonas aeruginosa and Pseudomonas putida isolates disseminated in a Korean hospital. Antimicrob Agents Chemother. 2002;46(4):1053-1058.

14. Yum JH, Yong D, Lee K, Kim HS, Chong YA. A new integron carrying VIM- 2 metallo- $\beta$-lactamase gene cassette in a Serratia marcescens isolate. Diagn Microbiol Infect Dis. 2002;42(3):217-219.

15. Jeong SH, Lee K, Chong Y, Yum JH, Lee SH, Choi HJ, et al. Characterization of a new integron containing VIM-2, a metallo-beta-lactmase gene cassettes, in a clinical isolate of Enterobacter cloacae. J Antimicrob Chemother. 2003;51(2):397-400.

16. Park C, Kim NH. Genetic diversity of imipenem-resistant bacteria. The Korea Entertainment Industry Association. 2013; 7(1):157-165.

17. Cohen SN, Chang ACY, Hsu L. Nonchromosomal antibiotic resistance in bacteria: Genetic transformation of Escherichia coli by R-factor DNA. Proc Natl Acad Sci USA. 1972;69(8): 2110-2114.

18. Hwang YM, Kim DK, Lee JH, Baik KS, Park C, Seong CN. Bacterial community of natural dye wastewater treatment facility. Journal of Life Science. 2014;24(4):393-402

19. Saitou N, Nei M. The neighbor-joining method:a new method for reconstructing phylogenetic trees. Mol Biol Evol. 1987; 4(4):406-425.

20. Jukes TH, Cantor CR. Evolution of protein molecules. In: Munro HN, editor. Mammalian protein metabolism. New York: Academic Press; 1969. p21-132.

21. Felsenstein J. Confidence limits on phylogenies: an approach using the bootstrap. Evolution. 1985;39(4):783-791.

22. Clinical and Laboratory Standards Institute. Performance standards for antimicrobial susceptibility testing; 24th Informational supplement, M100-S24. Wayne, PA: Clinical and Laboratory Standards Institute; 2014.

23. Frédéric B, Catherine B, Nicole LZ. Identification of PSE and OXA $\beta$-lactamase genes in Pseudomonas aeruginosa using PCR -restriction fragment length polymorphism. J Antimicrobial Chemotherapy. 2002;50(1):11-18.

24. Jang IH, Park SD, Uh Y, Lee GS, Kim JB, Choi I. Molecular characteristics of blaoxA-23-producing Acinetobacter baumannii isolated from a university hospital. Ann Clin Microbiol. 2013; 16(3):126-133.

25. Bosshard PP, Abels S, Zbinden R, Bottger EC, Ribosomal DNA sequencing for identification of aerobic gram positive rods in the clinical laboratory (an 18-month evaluation). J Clin Microbiol. 2003;41(9):4134-140. 